\title{
Is the Revitalisation of Smallholder Irrigation Schemes (RESIS) programme in South Africa a viable option for smallholder irrigation development?
}

\author{
Maatla Aaron Maepa', Godswill Makombe ${ }^{2 *}$ and Matshidiso Kanjere ${ }^{2}$ \\ ${ }^{1}$ Limpopo Department of Agriculture, Private Bag X9487, Polokwane, 0700, South Africa \\ ${ }^{2}$ University of Limpopo, Turfloop Graduate School of Leadership, PO Box 756, Fauna Park, 0787, South Africa
}

\begin{abstract}
Smallholder irrigation in South Africa comprises only 3\% of the irrigated area. Despite this relatively small area share, Limpopo Province is using the development of smallholder irrigation as a way of developing rural areas and correcting historical imbalances. Unlike the smallholder irrigation developed in most African countries, which focuses mainly on food security through subsistence production, Limpopo Province aims to develop commercial smallholder irrigation. Plots in this model are not fragmented. Initially the farmers are paired with a strategic partner knowledgeable about both the operation of irrigation and the crops grown. After 3 years the strategic partner transfers all ownership to farmers. We use gross margin analysis from one production cycle to assess the financial viability of this model. We conclude that there is potential for the model to be financially viable if farmers can get access to cash flow support in the form of credit which they can pay off at the end of a production cycle. This could be an innovative way of smallholder agricultural water management and of transforming poor subsistence farmers to commercial producers and thereby correcting historical imbalances.
\end{abstract}

Keywords: smallhoder irrigation, financial viability, gross margin, South Africa

\section{INTRODUCTION}

Smallholder irrigation involves many forms of water control, including rainwater harvesting, flood recession, flood water spreading, river diversion, treadle pumps, motor pumps, watering cans, porous jars and small dams and reservoirs. Some of the characteristics of smallholder irrigation that make it attractive when compared to large-scale irrigation are low investment and maintenance costs, ease of maintenance, enabling of water control for remote poor farmers, low management requirements, and potentially lesser negative environmental effects (Tafesse, 2003). Some of the concerns associated with smallholder irrigation include lack of investment, a focus on food self-sufficiency that may at times preclude commercial production, lack of provision of financial services like credit, difficulties in water allocation, distribution and charging, difficulties in organising maintenance, inadequate extension, lack of markets and lack of entrepreneurial and managerial skills (Tafesse, 2003; Makombe et al., 2007).

Smallholder irrigation systems can comprise farmers who use shared or individual water sources with one common characteristic, i.e., that the farmers own small plots that are subdivided and sometimes fragmented. Makombe et al. (2001), in a study from Zimbabwe, describe plot sizes ranging from 0.36 ha to 0.86 ha. Mpahlele et al. (2000), in a study of smallholder irrigation in South Africa, mention plot sizes ranging from as small as $600 \mathrm{~m}^{2}$ to as large as 10 ha. Makombe et al. (2007) describe smallholder irrigation systems in Ethiopia with average plot sizes of $0.45 \mathrm{ha}$. Thus plot sizes are variable but one

\footnotetext{
To whom all correspondence should be addressed.

용 +27 15 290-2836;

e-mail: godswill.makombe@ul.ac.za, makombeg@yahoo.com Received 30 September 2013; accepted in revised form 26 June 2014.
}

common characteristic is that farmers make independent decisions on their small plots, with regards to crops grown, crop management practices and water management. The individual scale of decision making sometimes presents challenges for scheme maintenance, water allocation and distribution, as does the small plot size, which also has implications for commercialisation, mechanisation and the use of some of the common sophisticated irrigation equipment that requires reasonably sized tracts of land, e.g., centre pivot.

\section{Smallholder irrigation in Africa}

Smallholder irrigation assumes different levels of importance in different countries in Africa. Table 1 shows the extent of smallholder irrigation development in selected African countries. Many African countries have unexploited irrigation potential. The contribution of smallholder irrigation ranges from $3 \%$ of developed irrigation in South Africa to $80 \%$ of developed irrigation in Tanzania (Tafesse, 2003; Backeberg and Sanewe, 2010; Van Averbeke et al., 2011).

South Africa is one of the few African countries that have highly developed water resources and irrigation. Slightly more than $83 \%$ of potentially irrigable land is already developed (Van Averbeke et al., 2011). However, Table 1 shows that smallholder irrigation covers only $47667 \mathrm{ha}$, which is a mere $3 \%$ of the developed irrigation area (Backeberg and Sanewe, 2010). Most of the smallholder irrigation schemes were developed during the apartheid era in what was known as the independent and semi-independent homelands.

\section{The South African Economy and Apartheid}

With a nominal GDP at market price of ZAR 3 trillion (1USD = 7.6 ZAR at time of study) in 2011 (Government of South Africa, 


\begin{tabular}{|l|c|c|c|c|c|}
\hline \multicolumn{7}{|c|}{ The extent of smallholder irrigation development in selected African countries } \\
\hline Country & $\begin{array}{c}\text { Total area } \\
\text { (million ha) }\end{array}$ & $\begin{array}{c}\text { Arable land } \\
\text { (\% of total) }\end{array}$ & $\begin{array}{c}\text { Irrigation } \\
\text { potential } \\
\text { (million ha) }\end{array}$ & $\begin{array}{c}\text { Total irrigation } \\
\text { area (ha) }\end{array}$ & $\begin{array}{c}\text { Smallholder irrigation (ha) } \\
\text { Figure in brackets indicates percentage } \\
\text { of total irrigation area }\end{array}$ \\
\hline Ethiopia & 110.0 & 13.2 & 3.60 & 161790 & $95320(59)$ \\
\hline Ghana & 23.8 & 10.0 & 1.90 & 19000 & $12700(67)$ \\
\hline Kenya & 58.0 & 9.9 & 0.35 & 91410 & $36190(40)$ \\
\hline Malawi & 11.8 & 3.6 & 0.16 & 57040 & $8900(16)$ \\
\hline Tanzania & 94.5 & 40.0 & 0.83 & 150000 & $120000(80)$ \\
\hline South Africa & $122.0^{1}$ & $13.7^{1,2}$ & $1.67^{2}$ & $1,399221^{3}$ & $47667(3)^{3}$ \\
\hline
\end{tabular}

Source: Tafesse, 2003

${ }^{1}$ Source: STATSSA, 2011

${ }^{2}$ Source: Backeberg and Sanewe, 2010

${ }^{3}$ Source: Van Averbeke et al., 2011

2011a), South Africa has the largest African economy. The estimated population in 2011 was 50.6 million (Government of South Africa, 2011b). This makes the South African per capita GDP equal to ZAR59 300, ranking $7^{\text {th }}$ in Africa. However, in 1994 democratic South Africa inherited an economy that had a highly unequal income distribution, a situation created during the apartheid years. Even given the very high per capita GDP, post-apartheid South Africa is faced with the acute problem of widespread poverty and inequality. To address the income inequality, South Africa has embarked on many forms of Black economic empowerment programmes, because most of the poor are Black. While economic empowerment benefits are being realised, mainly among the urban Black middle class, the majority of the Black people continue to live in poverty (Bhorat and Kanbur, 2006). The challenges facing South Africa include, but are not limited to, unemployment, landlessness, homelessness, lack of basic services, human immunodeficiency virus (HIV) and acquired immunodeficiency syndrome (AIDS), food insecurity and high levels of crime and violence (MisraDexter and February, 2010).

\section{Smallholder irrigation in Limpopo Province}

South Africa is divided into 9 provinces; Limpopo Province lies in the northeast of the country (Government of South Africa, 2011b). In 1996 the Limpopo Department of Agriculture (LDA) established the Agricultural and Rural Development Corporation (ARDC). This organisation became the government development agency for agricultural development (Van Averbeke and Mohamed, 2006; Lahiff, 2000). The main area of focus for this corporation was the former homelands of Gazankulu, Lebowa and Venda. The corporation managed smallholder irrigation schemes through a top-down command and support system, which turned out to be unsustainable (Tshuma, 2009).

The Limpopo Department of Agriculture realised that the ARDC policy was not producing the desired impact on the farmers' livelihoods, so all financial and management support was withdrawn and schemes were handed over to the farmers, thus leaving them to their own devices in terms of the responsibility for acquiring resources for production, which obviously presented a serious problem to the cash-constrained farmers (Denison and Manona, 2007). Consequently, most of the schemes were left fallow and unproductive or produced at subsistence levels well below potential (Stimie et al., 2001; Perret, 2002).

Even given its small contribution to total irrigation, it was felt that the smallholder irrigation systems could play an important role in rural development (Perret, 2002). Therefore, through a series of policy and programme transformations between 1996 and 2004, LDA tried to address the constraints to smallholder irrigation in South Africa, finally settling for a programme called the Revitalisation of Smallholder Irrigation Schemes (RESIS) in 2004. In the RESIS context smallholder irrigation does not refer to the fragmented plots that are usually found on many of the smallholder irrigation schemes in Africa and elsewhere, and where individual farmers make independent production decisions on the plots. The RESIS smallholder irrigators produce as a single commercial unit. Given that South African commercial agriculture is characterised by extensive, largely White-owned farms, the small size of the command area, combined with the small size of land that the beneficiaries are entitled to on the RESIS schemes, is what leads the schemes to be classified as smallholder.

\section{The RESIS programme in Limpopo}

The RESIS programme is meant to address the problems on the smallholder irrigation schemes with the following specific objectives; to improve agricultural productivity on the schemes; to enable the schemes to play a role in local economic development through improved incomes for beneficiaries, and to improve food security and thus generally improve the livelihoods of the rural communities where the schemes are situated (Government of South Africa; 2005, 2004). Although RESIS does not fall directly under any of the economic empowerment programmes, its objectives, if accomplished, will assist in these efforts.

The RESIS approach proposes to achieve the revitalisation of the schemes through rehabilitation, by the installation of new efficient infield irrigation systems, and provision of the necessary services such as water, electricity and access roads. This is meant to assist the smallholding farmers to use the irrigation schemes to pursue commercial production and thus move away from subsistence production (Denison and Manona, 2007). Further, RESIS was also associated with irrigation management transfer as the management of the resources of production is meant to eventually be completely transferred to the smallholder farmers (Perret, 2001).

There are 11 operational RESIS schemes in Limpopo Province; namely, Tšwelopele, also known as Praktiseer, Elandskraal, Homu, Krokodilheuwel, Mbahela, Makuleke, Mapela, Mogalatšane, Phetwane, Setlaboswana and Strydkraal (Maepa, 2011). Table 2 shows the major characteristics of the RESIS schemes. 
TABLE 2

Summary of completed and operational RESIS irrigation schemes in Limpopo Province

\begin{tabular}{|l|l|l|l|l|l|l|}
\hline Name of Scheme & $\begin{array}{l}\text { Command } \\
\text { area } \\
\text { irrigated } \\
\text { (ha) }\end{array}$ & Irrigation technology & $\begin{array}{l}\text { Planned beneficiaries } \\
\text { (current } \\
\text { beneficiaries) }\end{array}$ & $\begin{array}{l}\text { Land } \\
\text { entitlement } \\
\text { per } \\
\text { beneficiary } \\
\text { (ha) }\end{array}$ & Crops grown & $\begin{array}{l}\text { Cost of } \\
\text { rehabilitation } \\
\text { (ZAR) }\end{array}$ \\
\hline Krokodilheuwel & 243 & Floppy sprinklers & $202(188)$ & 1.20 & Maize, potatoes & 20267465 \\
\hline Mbahela & 102 & Floppy sprinklers & $100(86)$ & 1.20 & Maize, potatoes & 18717425 \\
\hline Makuleke & 195 & Centre pivots & $243(41)$ & 0.80 & $\begin{array}{l}\text { Maize, potatoes, cotton, } \\
\text { wheat, vegetables }\end{array}$ & 15008318 \\
\hline $\begin{array}{l}\text { Tšwelopele } \\
\text { (Praktiseer) }\end{array}$ & 440 & Floppy sprinklers & $312(75)$ & 1.41 & $\begin{array}{l}\text { Maize, potatoes, sugar } \\
\text { beans }\end{array}$ & 22503809 \\
\hline $\begin{array}{l}\text { Elandskraal } \\
\text { Homu }\end{array}$ & 180 & $\begin{array}{l}\text { Centre pivot } \\
\text { permanent overhead } \\
\text { sprinklers }\end{array}$ & $97(38)$ & 1.86 & Maize, potatoes, vegetables & 22064272 \\
\hline $\begin{array}{l}\text { Strydkraal } \\
\text { (Phase 1) }\end{array}$ & 34 & Micro/drip & $22(22)$ & 5.70 & Maize, pepperdew & 10815924 \\
\hline $\begin{array}{l}\text { Phetwane } \\
\text { (Hindustan) }\end{array}$ & 52 & Floppy sprinklers & $281(18)$ & 1.20 & Maize, potatoes, vegetables & 1996111 \\
\hline Mogalatjane & 131 & Floppy sprinklers & $98(98)$ & 1.21 & Maize, potatoes & 4956107 \\
\hline Setlaboswane & 119 & Floppy sprinklers & $99(96)$ & 1.34 & Maize, potatoes & 11430197 \\
\hline Mapela & 72 & $\begin{array}{l}\text { Floppy sprinklers } \\
\text { Drip irrigation }\end{array}$ & $57(60)$ & 1.20 & Maize, potatoes & 12185629 \\
\hline Total & 1694 & & 1.26 & Maize, vegetables & 12589988 \\
\hline
\end{tabular}

Source: (Maepa, 2011)

From Table 2 the total area under RESIS in Limpopo is 1 694 ha with 1554 planned and 770 current or active beneficiaries, at an estimated total rehabilitation cost of more than ZAR 150 million (Maepa, 2011). This is therefore a significant investment that is meant to contribute significantly towards improving the livelihoods of the rural poor who will benefit from it, and also to have an impact on income distribution in general. At the exchange rate mentioned earlier, the cost of the RESIS irrigation rehabilitation is just under 12000 USD/ ha. In comparison, in Zimbabwe the cost of developing irrigation ranges from 200 to 1000 USD (Makombe et al., 2001). Innocencio et al. (2007) estimated that the cost of new irrigation construction in Sub-Saharan Africa was about 14500 USD/ha and the cost of rehabilitation was just over 8200 USD/ ha. The cost of RESIS is therefore not out of range of other irrigation developments in Southern Africa. Furthermore, RESIS is managing to provide more sophisticated irrigation equipment than the average schemes evaluated by Innocenio et al. (2007). The schemes evaluated by Innocencio et al. (2007) were largely based on canal water delivery systems.

Table 2 also shows the current beneficiaries and the planned beneficiaries when development is finished. For instance, at Tšwelopele Irrigation Scheme (TIS) there are currently 75 of 312 planned beneficiaries. The installed irrigation technology differs at different sites, and comprises floppy sprinklers, centre pivots, overhead sprinklers, micro-drip, and sometimes combinations of these technologies. The common characteristic of the technologies across the schemes is that it is sophisticated and requires high levels of management to be effectively used. Tšwelopele Irrigation Scheme was formed in 2001 from a scheme that was established by the Bantu Investment Cooperation in 1977. Farmers operated their plots on an individual basis (Mpahlele et al., 2010). RESIS was involved with the revitalisation of about 126 smallholder irrigation schemes with an area of 19000 ha (Mpahlele et al., 2010). Table 1 shows the schemes for which revitalisation had been completed by the time of the study. At this time Tšwelopele operated 312 of the intended 440 ha and through RESIS these were no longer operated as individual plots but on a cooperative basis (as described by Maepa, 2011).

Table 2 also shows that the average land entitlement across the 11 schemes is 1.28 ha. This plot size is similar to the ones described above from other parts of Africa. As mentioned earlier, for RESIS, the command areas shown in Table 2 are not subdivided but produce as a commercial unit. The modus operandi at all of the schemes is similar in pattern, as follows: A strategic partner is identified. The strategic partner is a (White) commercial farmer who is experienced in producing selected crops. For TIS the strategic partner held $50 \%$ of the shares in the first and second years and $45 \%$ of the shares in the third year. By the end of the third year the strategic partner was supposed to transfer all of the management to the farmers. One of the objectives of the partnership is stated as to 'operate the irrigation scheme as part of the project of the Limpopo Department of Agriculture to its potential capacity on a profitable commercial basis'. 'Train farmers and transfer the required skills to empower them to be able to operate the irrigation scheme themselves in the long term which includes training in the areas of finance, quality control, marketing, management, operational, technical and business administration' (Government of South Africa, 2008 p. 2). Thus, it is clear that the LDA's intention is for the farmers to learn from the strategic partnership so that they can continue to produce at a commercial level. This makes this approach distinctly different 


\begin{tabular}{|l|c|c|}
\hline \multicolumn{3}{|c|}{ TABLE 3} \\
\multirow{2}{*}{ Crop budgets for 2002 ha of potato and Maize at TIS, 2009 (ZAR) } \\
\cline { 2 - 3 } & \multicolumn{2}{c|}{ Crop } \\
\hline Area planted & $\mathbf{2 0 2}$ & $\mathbf{6 0}$ \\
\hline Gross income & $\mathbf{1 2 2 5 6 \mathbf { 9 4 5 . 4 2 }}$ & $\mathbf{6 3 3 7 9 4 . 3 6}$ \\
\hline Variable cost & & \\
\hline Seeds & 4155140.00 & 123420.12 \\
\hline Fertiliser & & 62243.28 \\
\hline At planting & 1252400.00 & \\
\hline Top dressing & 1036993.18 & \\
\hline Lime & 253714.02 & \\
\hline Temik (insecticide) & 596304.00 & 31500.00 \\
\hline Other chemical (insecticide and herbicide) & 662528.00 & 4247.00 \\
\hline Fuel (Diesel) & 435844.39 & \\
\hline Transport (Seed and Machinery) & 500102.37 & 4800.00 \\
\hline Spares and Repairs(Floppy \& Electrical repairs) & 288457.33 & 22686.23 \\
\hline Electricity & 182747.08 & 89404.45 \\
\hline Wages (planting and harvesting) & 907335.59 & 137075.50 \\
\hline Security (January 2009 - August 2009) & 11400.00 & 1000 \\
\hline & & \\
\hline Total variable cost & $\mathbf{1 0 2 8 2 9 6 5 . 9 6}$ & $\mathbf{4 7 6 3 7 6 . 5 8}$ \\
\hline Gross margin (profit) & $\mathbf{1 9 7 3 9 8 0 . 0 0}$ & $\mathbf{1 5 7 4 1 7 . 7 8}$ \\
\hline Source: (Maepa 2011) & & \\
\hline
\end{tabular}

Source: (Maepa, 2011)

from the approach used to develop smallholder irrigation schemes where subsistence is part of the objectives.

\section{METHODOLOGY}

Due to both budget and time constraints, one scheme of TIS was purposively selected as an easily accessible scheme and one based on the floppy sprinkler irrigation system used at 8 of the 11 completed RESIS sites. Although there are only 75 beneficiaries, due to budget and time constraints a random sample of 50 farmers was selected for data collection through a survey. Two meetings were held with the RESIS beneficiaries. One was largely used to explain the purpose of the study and the second was used to sharpen the questions in the survey. Beneficiaries were asked about their perceptions of their livelihoods before and after the RESIS program. Data complementary to that collected from beneficiaries was collected from key informants, for instance, agricultural technicians at the scheme and local political and economic development leaders, using semi-structured interviews. Farm records kept at LDA and on the scheme were used to calculate enterprise gross margins.

\section{RESULTS AND DISCUSSION}

\section{Crop budgets for operations at Tšwelopele Irrigation Scheme}

The financial performance of TIS was made using crop budgets for one completed growing cycle of 2009/10. In February 2009, 224 ha of potatoes were planted, which were harvested in August/September 2009. Concurrently, 174 ha of sugar beans were also grown and were harvested in July 2010. Sixty (60) ha of maize were planted in November/December 2009 and harvested in March/April 2010, completing one growing cycle (Maepa, 2011). Given that the current irrigated area of TIS developed under RESIS is 400 ha, more land could have been planted to maize. However, there was a conflict with the strategic partner, which not only led to less maize being grown, but also led to the late harvesting of the maize, potentially disrupting the following production cycle (Maepa, 2011).

Tables 3 and 4 show the crop budgets for potatoes, maize and beans. The potatoes are a very lucrative crop. The potatoes are a specific variety, the seed for which is produced in The Netherlands. As can be seen from Table 3 the seed is expensive, costing $20570 \mathrm{ZAR} / \mathrm{ha}$. However, if the potatoes meet certain specifications, they are bought by a South African company that makes Simba Chips. If the specifications are met by the crop, as was the case for TIS during the season that was analysed, potato production is very profitable.

Tables 3 and 4 also show that the total income, based on the gross margin from the operations at TIS for one production cycle, is ZAR 2652 067.29, which means that, after accounting for the $50 \%$ paid to the strategic partner, each beneficiary received ZAR 17680 . We note that these gross margins are actually profit since all production costs are accounted for at cost. From Table 2 the development cost at TIS is ZAR 22503 809. This means that, using straight line depreciation, at this production rate TIS will recover its development cost in 8.5 years. We also note that it is necessary to estimate the amount received by beneficiaries after accounting for annual depreciation for each type of equipment as this would reflect the necessary irrigation equipment reinvestment. We could not do this because we did not have all the necessary data related to the equipment; hence the estimated investment recovery period is based on straight line depreciation.

The crop budget for beans in Table 4 is presented as a cash flow to demonstrate that even though a crop has a defined growing period, there are expenses associated with it throughout the whole year. These expenses need to be planned for, especially for the times of the year when the cash flow is negative. 


\begin{tabular}{|c|c|c|c|c|c|c|c|c|c|c|c|c|c|c|c|c|c|c|c|c|c|c|}
\hline & 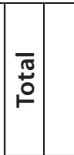 & 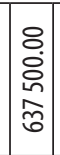 & $\begin{array}{l}0 \\
0 \\
0 \\
0 \\
o \\
\text { f }\end{array}$ & $\mid \begin{array}{c}0 \\
0 \\
\vdots \\
\vdots \\
\vdots \\
\vdots \\
\vdots\end{array}$ & $\begin{array}{l}0 \\
\vdots \\
0 \\
\vdots \\
\vdots \\
\vdots \\
\infty\end{array}$ & 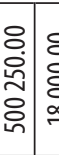 & 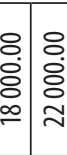 & 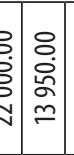 & 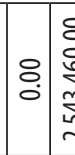 & 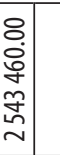 & 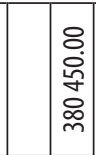 & 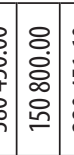 & 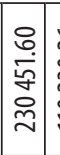 & 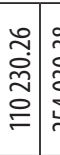 & 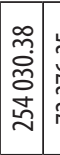 & 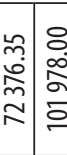 & 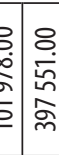 & $\mid \begin{array}{l}0 \\
0 \\
0 \\
0 \\
0 \\
0 \\
0\end{array}$ & 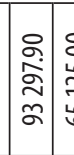 & 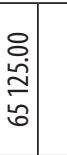 & 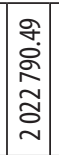 & 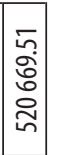 \\
\hline & Ф̆ & & & & & & & & & 영 & & $\begin{array}{l}8 \\
0 \\
0 \\
0 \\
0 \\
0\end{array}$ & 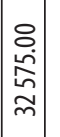 & & \begin{tabular}{|c|} 
\\
0 \\
0 \\
$o$ \\
$\sigma$ \\
$\sigma$
\end{tabular} & & & & & & 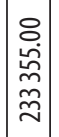 & 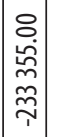 \\
\hline & zo & & & & & & & 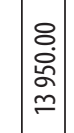 & & 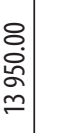 & & & 足 & 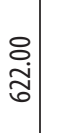 & & & & & & & 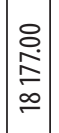 & 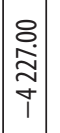 \\
\hline & t̆ & & & & $\begin{array}{l}0 \\
\vdots \\
\vdots \\
\vdots \\
\vdots \\
0 \\
\vdots\end{array}$ & 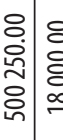 & 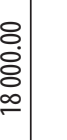 & & & 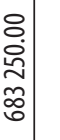 & & & & & & 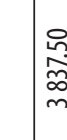 & 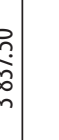 & & & & 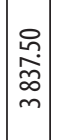 & 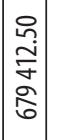 \\
\hline & $\mid \begin{array}{l}\text { ڤे } \\
\text { | }\end{array}$ & & & & $\begin{array}{l}0 \\
\dot{a} \\
\tilde{\Xi} \\
\approx \\
\approx\end{array}$ & & & & & 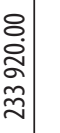 & & & & & & $\begin{array}{l}\text { o. } \\
\text { ఏे } \\
\text { m. }\end{array}$ & : & & & & $\mid \begin{array}{l}0 \\
\grave{\vdots} \\
\grave{0} \\
m \\
m\end{array}$ & 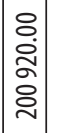 \\
\hline & \begin{tabular}{|l|}
$\mid 0$ \\
$\frac{9}{4}$
\end{tabular} & & & & & & $\begin{array}{l}\stackrel{8}{0} \\
\text { ठे } \\
\text { ন }\end{array}$ & s. & & 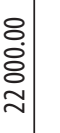 & & & & & & & & & & & 임 & 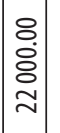 \\
\hline 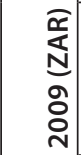 & & & 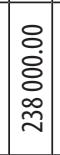 & & 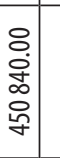 & & & & & 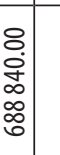 & & & & & & 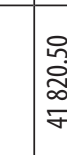 & 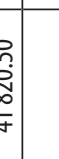 & & & & 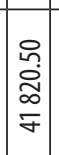 & $\left|\begin{array}{l}0 \\
0 \\
\vdots \\
\vdots \\
\hat{\sigma} \\
\hat{f}\end{array}\right|$ \\
\hline 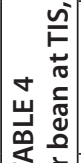 & ફ & $\begin{array}{c}8 \\
0 \\
0 \\
\tilde{\sigma} \\
\approx \\
\end{array}$ & \begin{tabular}{l}
0 \\
0 \\
0 \\
0 \\
$o$ \\
$\approx$ \\
\hdashline
\end{tabular} & $\begin{array}{l}8 \\
\vdots \\
\vdots \\
0 \\
0 \\
0\end{array}$ & & & & & & 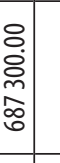 & & & 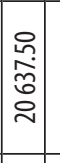 & & & & & & & $\begin{array}{l}8 \\
\dot{d} \\
\text { an } \\
\text { ని }\end{array}$ & 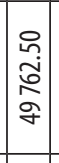 & $\left|\begin{array}{l}0 \\
\stackrel{0}{0} \\
\hat{\tilde{n}} \\
\hat{\tilde{\theta}} \\
\mid\end{array}\right|$ \\
\hline $\mid \begin{aligned} 10 \\
0 \\
\vdots \\
\vdots \\
\vdots \\
\vdots \\
3\end{aligned}$ & $\stackrel{\vec{\sigma}}{\sum}$ & 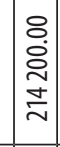 & & & & & & & & 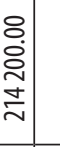 & & & $\begin{array}{l}8 \\
0 \\
0 \\
2 \\
2 \\
R\end{array}$ & 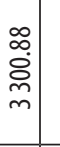 & & & & & & $\begin{array}{l}0 \\
8 \\
\dot{0} \\
0 \\
0\end{array}$ & $\left|\begin{array}{l}\infty \\
0 \\
0 \\
0 \\
0 \\
0 \\
0\end{array}\right|$ & $\mid \begin{array}{l}\approx \\
\approx \\
\alpha \\
0 \\
0 \\
0\end{array}$ \\
\hline 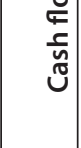 & & & & & & & & & & ¿ & & & & & & & 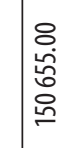 & & & & \begin{tabular}{|l|} 
\\
0 \\
0 \\
0 \\
0 \\
0 \\
0
\end{tabular} & \begin{tabular}{|l|} 
\\
0 \\
$\omega$ \\
0 \\
0 \\
0 \\
\hdashline \\
1
\end{tabular} \\
\hline & $\sum^{\pi}$ & & & & & & & & & ¿̊. & & & & 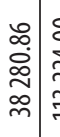 & 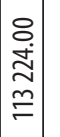 & & 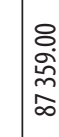 & & & & $\left|\begin{array}{l}\infty \\
\infty \\
0 \\
\infty \\
\approx \\
\approx\end{array}\right|$ & 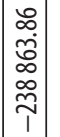 \\
\hline & $\frac{\stackrel{0}{0}}{4}$ & & & & & & & & & ¿ & & & 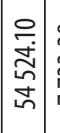 & 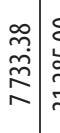 & $\begin{array}{c}8 \\
0 \\
0 \\
0 \\
\bar{m} \\
\vdots \\
\vdots\end{array}$ & 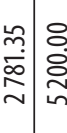 & مُ & 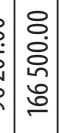 & 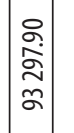 & & 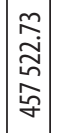 & 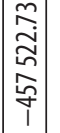 \\
\hline & 初 & & & & & & & & & 8 & \begin{tabular}{|l|}
0 \\
0 \\
0 \\
0 \\
0 \\
0 \\
$m$
\end{tabular} & $\begin{array}{l}b_{0} \\
\vdots \\
\vdots \\
\vdots \\
\vdots\end{array}$ & $\begin{array}{l}8 \\
0 \\
0 \\
0 \\
m \\
m\end{array}$ & 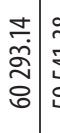 & 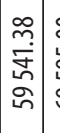 & 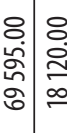 & 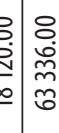 & & & & 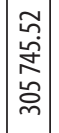 & 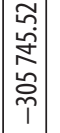 \\
\hline & క్ & 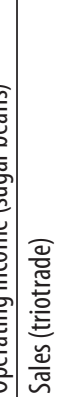 & 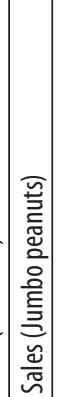 & 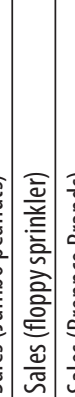 & 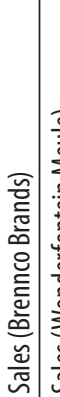 & 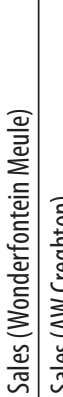 & 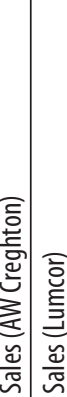 & 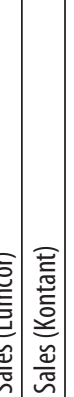 & 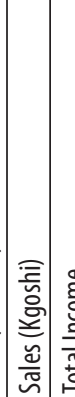 & 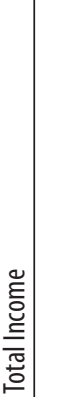 & 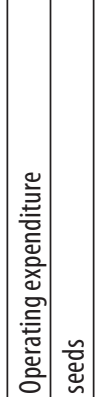 & 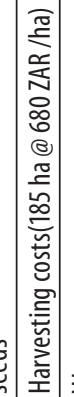 & 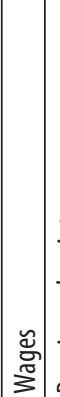 & 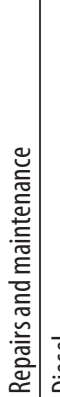 & $\overline{\widetilde{\Xi}}$ & 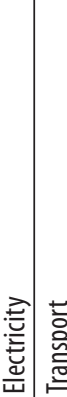 & 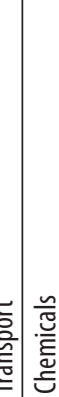 & 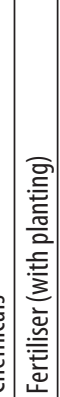 & 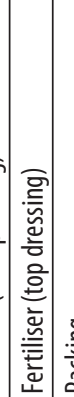 & . & 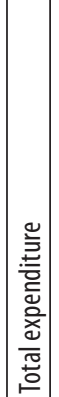 & 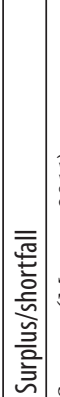 \\
\hline
\end{tabular}




\begin{tabular}{|c|c|c|c|c|}
\hline \multicolumn{5}{|c|}{$\begin{array}{l}\text { TABLE } 5 \\
\text { Perceptions of the impact of RESIS on beneficiaries' livelihoods (\%) }\end{array}$} \\
\hline \multirow{2}{*}{$\begin{array}{l}\text { Proxies for livelihoods } \\
\text { impact }\end{array}$} & \multicolumn{4}{|c|}{ Impact category level } \\
\hline & Very high & High & Low & Very low \\
\hline Household income & 42 & 34 & 14 & 10 \\
\hline Household assets & 43 & 33 & 12 & 12 \\
\hline Diversifying income & 33 & 38 & 15 & 15 \\
\hline Diversifying skills & 44 & 30 & 17 & 9 \\
\hline On-farm employment & 44 & 32 & 12 & 12 \\
\hline Off-farm employment & 22 & 18 & 41 & 18 \\
\hline Access to food & 44 & 32 & 12 & 12 \\
\hline Social networking & 44 & 34 & 10 & 12 \\
\hline
\end{tabular}

Source: Maepa (2011)

We observe that this will be one of the major challenges for smallholders producing under this model, as they will definitely need good financial planning for sustainability. Financial support could also be provided through a government credit scheme. Given the financial performance of TIS during the $2009 / 10$ production cycle, it is possible to successfully design a credit scheme that can support such a production cycle. This will be a challenge that the government and the smallholders will have to overcome but the current approach taken by LDA seems to produce the desired results. There is also the possibility of the private sector being involved in this credit system as this model is anticipated to operate fully at a commercial level and shows good signs of being profitable.

An element of sustainability is that the lifespan of the irrigation equipment needs to be estimated and the smallholders need someone to advise them on a reinvestment plan, whereby they set aside some of the profit that they can use to purchase equipment as it depreciates and needs replacement. This is a critical component for the long-term sustainability of the projects.

\section{Beneficiaries' perceptions of the RESIS programme}

The financial possibilities that are created by RESIS are clearly demonstrated by the gross margin analysis. However, further to this, beneficiaries were asked about their perceptions of the impact of RESIS on their livelihoods. The responses are summarised in Table 5. The perceptions were focused on whether beneficiaries perceived RESIS to have had a positive impact on their household incomes, household assets, diversification of income, diversification of skills, on-farm employment, off-farm employment, access to food and social networking. Participants were asked to classify the impact of RESIS on each of these variables in the categories 'very high', 'high', 'low' and 'very low' impact.

From Table 5, 76\% of the beneficiaries' perceptions indicated that RESIS had high positive impacts on household income, with $42 \%$ reporting that RESIS's impact on income is 'very high' and 34\% responding that the RESIS income impact is 'high'. This is consistent with the budget analysis; however, there are a few who thought the income impact was low. In terms of household assets, more than $75 \%$ reported that RESIS has a positive impact on household asset ownership. This means that they have acquired more household assets compared to assets they possessed before the introduction of the RESIS programme. More than $70 \%$ reported that the income diversification from RESIS is high. This statistic is possibly a result of the fact that RESIS introduced new income sources which participants did not have prior to its introduction.

More than $74 \%$ of the participants reported that the introduction of RESIS has led to skills diversification. One of the conditions for RESIS is that the participants are partnered with a strategic partner who has extensive knowledge of the crops that are being grown by the RESIS project, namely, potatoes, maize and sugar beans. Therefore diversification of skills acquired by the beneficiaries is through the interaction with the knowledgeable strategic partner on their daily farming activities. This learning part is critical to the long-term sustainability of this model. Smallholders need to learn how to manage the farm as a commercial enterprise.

RESIS participants were asked whether they felt that the RESIS project had an impact on off-farm employment. Slightly less than $60 \%$ reported that the impact of RESIS on off-farm employment is 'low' or 'very low'. This is consistent with the fact that RESIS is being used by the government to encourage agricultural production and therefore on-farm employment. In fact $76 \%$ reported that RESIS has a high impact on on-farm employment, as shown by Table 5 . Seventy-six per cent (76\%) of the participants reported that RESIS has as high impact on access to food. Seventy-eight per cent $(78 \%)$ of the participants responded that RESIS has a high impact on social networking, (i.e. specific types of interdependency, such as funeral societies, business clubs, farmers' associations and financial exchange clubs (stokvels)). Although it is relatively easy to understand the respondents' perceptions of the impact of RESIS on most of the variables discussed above, it would be interesting to investigate why farmers perceive that RESIS has a high impact on social networks. Perhaps as the farmers learn the new skills from the strategic partner this might lead to more interaction between them, and hence an enhancement in social networks. Generally, key informants concurred with the perceptions of the beneficiaries (Maepa, 2011).

\section{CONCLUSION}

This model of smallholder irrigation addresses most of the concerns related to smallholder irrigation mentioned earlier. Of particular note is that it is a bold step towards transforming smallholder irrigation from food self sufficiency and subsistence to commercial production.

The model will only be an option where specific conditions are met. For example, land needs to be large enough to be able to use the sophisticated irrigation equipment, capital for development must not be limiting, farmers must be willing to 
forego the ability to make independent decisions, farmers need to agree on a reinvestment strategy and the operation's cash flow needs to be financed, possibly through a credit scheme. From the analysis of one cycle at Tšwelopele the model appears to be viable.

Perhaps we should refer to this irrigation as 'smallholding irrigation', as implied in the title of the article by Perret (2002), to reflect the size of the land entitlements and to differentiate it from 'smallholder irrigation' where farmers own individual plots for which they make independent decisions. This model is tantamount to beneficiaries owning shares in a commerciallyrun enterprise with the size of their landholding defining their share. The model shows promising signs as an innovative approach to agricultural water management by resource-poor farmers. We conclude that, where there is a fit with this model, it should be encouraged for smallholder farmers.

\section{REFERENCES}

BACKEBERG GR and SANEWE AJ (2010) Towards productive water use and household food security in South Africa. Paper presented at the $6^{\text {th }}$ Asian Regional Conference of ICID, 10-16 October 2010, Indonesia

BHORATH and KANBUR R (EDS) (2006) Poverty and Policy in Postapartheid South Africa. Human Science Research Council Press, Pretoria.

DENISON J and MANONA S (2007) Principles, approaches and guidelines for the participatory revitalization of smallholder irrigation schemes. Volume 1: A rough guide for irrigation development practitioners. WRC Report No. TT 309/07. Water Research Commission, Pretoria.

GOVERNMENT OF SOUTH AFRICA (2004) Limpopo Department of Agriculture. Report on Directorate: Farmer Settlement, Research and Education Unpublished, Polokwane.

GOVERNMENT OF SOUTH AFRICA (2005) Limpopo Department of Agriculture. Limpopo Revitalisation of Smallholder Irrigation Scheme Policy Unpublished, Polokwane.

GOVERNMENT OF SOUTH AFRICA (2008) Limpopo Department of Agriculture. Memorandum of agreement entered into and between Tswelopele Farmers Cooperative and Temong CC Trading as Arthur William Creighton LDA, Polokwane.

GOVERNMENT OF SOUTH AFRICA (2011a) Gross domestic product, Fourth quarter, (2011)URL: http://www.statssa.gov (Accessed 4 May 2012).

GOVERNMENT OF SOUTH AFRICA (2011b) South African Provinces' available at (2011) URL: http://www.statssa.gov.za/ censusatschool/docs/Web Province.pdf (Accessed 4 May 2012).

INOCENCIO A, KIKUCHI M, TONOSAKI M, MARUYAMA A, MERREY D, SALLY H, and DE JONG I (2007) Costs and performance of irrigation projects: A comparison of sub-Saharan Africa and other developing regions. Unpublished IWMI Research Report 109.

LAHIFF E (2000) An Apartheid Oasis: Agriculture and Rural Livelihoods in Venda. Frank Cass Publishers, London.
MAEPA MA (2011) An impact assessment of the Revitalisation of Smallholder Irrigation Schemes program: A case of Tšwelopele irrigation scheme in Sekhukhune District of Limpopo Province. M.Sc. thesis, Turfloop Graduate School of Leadership, University of Limpopo, South Africa,

MAKOMBE G, DAVIES SP, SAMPATH RK and MEINZEN-DICK R (2001) An evaluation of bani (dambo) systems as a smallholder irrigation development strategy in Zimbabwe. Can. J. Agric. Econ. 49 203-216.

MAKOMBE G, KELEMEWORK D and AREDO D (2007) A comparative analysis of rainfed and irrigated agricultural production in Ethiopia. Irrig. Drain. Syst. 21 35-44. DOI: http://dx.doi. org/10.1007/s10795-007-9018-2.

MISRA-DEXTER N. and FEBRUARY J (EDS) 2010) Testing Democracy - Which Way is South Africa Going? IDASA, ABC Press, Cape Town.

MPAHLELE RE, MALAKALAKA TM and HEDDEN-DUNKHORST $\mathrm{B}$ (2000) Characteristics of smallholder irrigation farming in South Africa: a case study of the Arabie-Olifants River Irrigation Scheme. IWMI South Africa Working Paper 3. International Water Management Institute (IWMI), Colombo. 32 pp.

MPHAHLELE RB, NESAMVUNI AE, GROENEWALD I and DAGADA MC (2010) The impact of government intervention on small scale irrigation schemes in Sekhukhune District: A case study of the Tšwelopele Scheme. Paper presented at the South African Society for Agricultural Extension Conference: The Impact of Climate Change on Extension Delivery in South Africa, 4-7 May 2010, Langebaan.

PERRET SR (2001) New water policy, irrigation management transfer and smallholding irrigation schemes in South Africa: Institutional challenges. Working Paper 18053, University of Pretoria, Department of Agricultural Economics, Extension and Rural Development. University of Pretoria, Pretoria.

PERRET SR (2002) Testing scenarios on the viability of smallholding irrigation schemes in South Africa: A participatory and information-based approach. Paper presented at: Conference of the International Farming Systems Association, November 2002, Orlando, Florida, USA.

STIMIE C, RICHTERS E, THOMPSON H, PERRET S, MATETE M, ABDALLAH K, KAU J and MULIBANA E (2001) Hydroinstitutional mapping in the Steelpoort River Basin, South Africa. Working Paper 17 (South Africa Working Paper No. 6). Colombo, Sri Lanka: International Water Management Institute.

TAFESSE M (2003) Small-scale irrigation for food security in subSaharan Africa. ACP-EU Technical Centre for Agricultural and Rural Cooperation (CTA) Working Document Number 8031 (unpublished). ACP-EU Technical Centre for Agricultural and Rural Cooperation, Addis Ababa.

TSHUMA MC (2009) A Socio-Economic Impact Assessment (SEIA) of the best Management Practices (BMP) Project of the Zanyokwe Irrigation Scheme at Farm Level. M.Sc. thesis, University of Fort Hare.

VAN AVERBEKE W and MOHAMED SS (2006) Smallholder irrigation schemes in South Africa: Past, present and future. Paper presented at: $2^{\text {nd }}$ Symposium of the South African National Committee on Irrigation and Drainage, 15-17 November 2006, Aventura Swadini. 
http://dx.doi.org/10.4314/wsa.v40i3.13 Available on website http://www.wrc.org.za

ISSN 0378-4738 (Print) = Water SA Vol. 40 No. 3 July 2014 ISSN 1816-7950 (On-line) = Water SA Vol. 40 No. 3 July 2014 